\title{
Study on the impact of the system of rice intensification in less water endowed areas of Tamil Nadu
}

\author{
V. MANIVANNAN*, K.R. JAHANMOHAN ${ }^{1}$, B.J. PANDIAN AND C. HARISUDHAN ${ }^{2}$ \\ Tamil Nadu Agricultural University, COIMBATORE (T.N.) INDIA \\ (Email : manivannangingee@gmail.com)
}

\begin{abstract}
System of rice intensification (SRI) is a novel method of rice cultivation based on a set of simple synergistic practices. They aim to change the management of rice plants and soil, water and nutrients that supports them in simple but specific ways. Success of SRI depends on strict adoption of its five major components viz., young seedlings with mat nursery, single seedling planting, square planting, alternate wetting and drying of irrigation management and mechanical weeder usage. Among the five components, raising young seedling in the mat nursery, planting single seedling and square planting are the most important components that paves the way for increasing the yield of rice crop in irrigated rice systems. Proponents of SRI have reported that the average rice yield with SRI can be doubled from the current average yield level and there exists potential to the tune of increasing the yield level by three to four times. An attempt was made to evaluate the impact of adoption of SRI practices on rice yields, its economics in rice cultivation and labour inputs based on field research conducted in Varahanadhi Sub Basin, Villupuram and Tiruvannamalai districts, Tamil Nadu State, India. Rice yields with SRI were higher than those under conventional paddy cultivation by 34.35 per cent and net returns were higher by 33.24 per cent. SRI adoption enabled farmers consistently to enhance rice yields, increase returns and save labour cost and enhance productivity with respect to the key inputs in terms of rice output per unit of seed, water and fertilizer. SRI promises to be a significant alternative not only for raising rice yields, but also for managing rice based farming in wet lands ecosystem.
\end{abstract}

Key Words : System of rice intensification (SRI), Rice yield, Tamil Nadu

View Point Article : Manivannan, V., Jahanmohan, K.R., Pandian, B.J. and Harisudhan, C. (2016). Study on the impact of the system of rice intensification in less water endowed areas of Tamil Nadu, India. Internat. J. agric. Sci., 12 (2) : 234-237, DOI:10.15740/HAS/IJAS/ 12.2/234-237.

Article History : Received : 25.01.2016; Revised : 18.02.2016; Accepted : 21.04.2016

\footnotetext{
* Author for correspondence:

${ }^{1}$ State Planning Commission, CHENNAI (T.N.) INDIA

${ }^{2}$ Regional Research Station, Virudhachalam, CUDDALORE (T.N.) INDIA
} 